\title{
Paradoks Etika Pemanfaatan Teknologi Informasi di Era 5.0
}

\author{
Arya Bimantoro ${ }^{1}$, Wanda Alifiyah Pramesti ${ }^{2}$, Satria Wira Bakti ${ }^{3}$, M Aryo Samudra $^{4}$, Yusuf Amrozi ${ }^{5}$ \\ 1,2,3,4,5 Program Studi Sistem Informasi, Fakultas Sains dan Teknologi \\ UIN Sunan Ampel Surabaya \\ Email: yusuf.amrozi@gmail.com
}

\begin{abstract}
Abstrak
Perkembangan teknologi informasi telah mempengaruhi aspek-aspek kehidupan, terutama pada aspek sosial berupa perubahan pola interaksi sosial sebagai fokus di era Society 5.0 ini. Hal ini tentu saja menjadi tantangan bagi masyarakat bukan hanya pada bagaimana beradaptasi dengan perubahan yang serba berbasis teknologi saat ini tetapi juga berinteraksi dengan sesama yang mulai dengan cara yang berbeda. Dengan menggunakan metode penelitian kualitatif, artikel ini bertujuan mengkaji tantangan dan kesiapan masyarakat saat ini. Kesiapan masyarakat dalam menyambut dan menghadapi era 5.0 perlu diketahui dan ditinjau. Berdasarkan hasil dan pembahasan etika masyarakat saat ini jauh berbeda dengan masyarakat dahulu dimana seharusnya perkembangan teknologi membawa perubahan yang baik untuk lingkungan. Pemanfaatan teknologi yang tidak diikuti etika yang baik melahirkan permasalahan sosial yang menimbulkan dampak negatif. Perubahan yang terjadi ini menjadi tantangan sekaligus peluang bagi mereka yang membutuhkan lapangan pekerjaan dan juga menciptakan lapangan kerja baru. Etika masyarakat dalam memanfaatkan teknologi informasi diperlukan pembelajaran yang baik karena pada era 5.0 cara berfikir masyarakat harus dibiasakan untuk kritis, analisis, dan kreatif.
\end{abstract}

Kata Kunci: Teknologi, Era 5.0, Paradoks, Etika, Masyarakat.

\begin{abstract}
The development of information technology affects a various aspects of life, especially on the social interaction patterns as a focus in this era of society 5.0. This is of course a challenge for the community on how to adapt to today's technology-based changes and interact with others who starts in different ways. Using qualitative methods, this article aims to examine the challenges and readiness of today's society. The community's readiness to welcome and face the 5.0 era needs to be knows and reviewed. Based on the results and discussion of ethics, today society is much different from the past, where technological developments should bring good changes to the environment. The use of technology that is not followed by good ethics gives rise to social problems that have a negative impact. These changes are a challenge and an opportunity for those who need jobs and create new jobs. Community ethics in utilizing information technology requires good learning because in 5.0 era people's way of thinking must be accustomed to being critical, analytycal, and creative.
\end{abstract}

Keyword: Technology, 5.0 era, paradox, ethics, community. 


\section{PENDAHULUAN}

Teknologi merupakan suatu kumpulan alat, aturan, dan juga prosedur yangg merupakan penerapan dari sebuah pengetahuan ilmiah terhadap sebuah pekerjaan tertentu dalam suatu kondisi yang dapat memungkinkan terjadinya perulangan (Manuel Castell,2004). Pada era sekarang teknologi dan sistem informasi berkembang sangat pesat. Teknologi menjadi semakin canggih dan dapat menunjang berbagai aktivitas serta membuat manusia bisa menggunakan berbagai macam peralatan berteknologi untuk membantu menjalankan berbagai aktivitas sebagai sarana pendukung produktivitas. Perkembangan teknologi harus diikuti perkembangan sumber daya alam dan manusianya.

Teknologi informasi adalah suatu alat yang digunakan para manager untuk bisa mengatasi perubahan yang terjadi (Kenneth $\mathrm{C}$. Loudon,2004). Teknologi informasi membantu manusia untuk memperoleh informasi dari berbagai macam sumber secara cepat. Dalam Oxford English Dictionary, Teknologi informasi adalah gabungan antara perangkat lunak dan perangkat keras. Namun, penggabungan ini tidak sebanding.

Perkembangan perangkat keras cenderung dari ukuran besar ke ukuran yang lebih kecil dengan kemampuan dan kapasitas yang lebih tinggi memiliki harga yang relatif murah. Perkembangan teknologi informasi ini membuat peningkatan kinerja dan memiliki kemungkinan berbagai macam pekerjaan dapat dilakukan dengan cepat, tepat, dan akurat. Berbagai manfaat teknologi informasi sangat banyak, contohnya di dunia telekomunikasi manfaatnya yaitu memudahkan kita berhubungan dengan orang lain hanya dengan menggunakan telepon. Selain itu, dalam dunia pendidikan, teknologi informasi memberi kemudahan dalam pengelolaan data dengan komputer, memudahkan siswa dalam pengumpulan tugas dan memudahkan pengaja untuk belajar secara daring atau disebut $e$ learning.
Perkembangan teknologi juga memunculkan trendsenter di berbagai jenis aktivitas yang berbasis dengan teknologi seperti e-commerce, e-goverment, e-education, $e$ medicine, e-laboratory, e-library, e-journal, dan lain-lain. Hal ini sudah diimplementasikan pada era 4.0 dimana teknologi dijalankan oleh sumber daya manusia sebagai kunci. Seperti yang diketahui perkembangan teknologi saat ini sudah berada diakhir era revolusi industri 4.0.

Perkembangan teknologi industri dimulai sejak awal peradaban manusia. Pada awal-awal kehidupan, teknologi tentunya masih minim sekali dan sangat bergantung pada alam seperti berburu, memetik apapun yang ada disekitar,dan memanfaatkan apapun yang ditemukan. Hal ini diyakini sebagai pola society 1.0 disebut hunting society. Seiring berjalannya waktu dan meningkatnya keilmuan dan kecerdasan manusia saat itu mulai mengetahui cara mendapatkan makanan yang berubah dari mengumpulkan menjadi menanam dan masa ini mulai dikenal dengan tatanan sosial. Masa ini dikenal dengan revolusi society 2.0 disebut agricultural society. Selanjutnya perkembangan mulai pesat dengan pola kerja yang beralih dari tenaga manusia ke penggunaan mesin. Di masa ini pencapaian terbesar yaitu produksi massal mesin sehingga era 3.0 disebut industrial society. Selanjutnya revolusi industri memasuki fase yang menggunakan jaringan internet yang disebut revolusi industri 4.0. Istilah revolusi industri 4.0 dikenalkan oleh ekonom dari Jerman yang bernama Prof. Klaus Schwab dalam bukunya The Fourth Industrial Revolution. Semua negara di dunia memasuki era revolusi industri 4.0 dengan sederet teknologi yang menjadi sendi kehidupan masyarakat.

Memasuki era revolusi digital sejak revolusi industri 4.0 dan sekarang tengah berkembang era 5.0. Dimana konsep ini memungkinkan kita untuk mempelajari ilmu pengetahuan yang berbasis modern seperti $\mathrm{Al}$, robot, loT, dan sebagainya. Era 5.0 pertama kali dicetuskan oleh pemerintahan Jepang yang menjelaskan dimana revolusi kehidupan masyarakat memanfaatkan teknologi dan mempertimbangkan humaniora dan aspek manusia. Society 5.0 cenderung artificial 
intelligence yang mengumpulkan jutaan data melalui internet untuk segala bidang kehidupan. Konsep ini merujuk pada masyarakat sekarang yang cenderung memilih hal-hal yang instan karena cepat dan praktis. Masyarakat semakin tidak terpisahkan dari teknologi dalam kesehariannya. Eletrifikasi dan digitalisasi mengubah cara mereka beraktivitas, mulai dengan urusan personal hingga urusan negara dan global. Kebutuhan akan teknologi semakin meningkat seiring berjalannya waktu. Masyarakat saat ini haus sekali akan teknologi. Namun, hal ini tidak diikuti dengan kapasitas dari teknologi yang terkadang tidak bisa menyelesaikan atau membantu seratus persen dari kebutuhan masyarakat.

Pada era 5.0 direncanakan hampir seluruh aspek kehidupan akan terlibat seperti perkembangan ekonomi, kebutuhan energi, kebutuhan pangan, pendidikan, kesehatan, tempat tinggal, industri, dan lain-lain. Perkembangan teknologi pada akhirnya akan mengubah cara pandang, perilaku, sifat, dan karakteristik interaksi sosial dengan kemajuan teknologi.

Sumber daya manusia mejadi objek yang paling merasakan perkembangan teknologi informasi yang menuju 5.0. Pengaruh teknologi informasi terhadap berbagai aspek kehidupan terutama aspek sosial tentang interaksi sosial. Dalam Theory of Reasoned Action (1975) menyatakan bahwa seseorang akan mengunakan teknologi informasi jika hal itu bermanfaat untuk meningkatkan kinerjanya. Pemanfaatan teknologi sudah banyak digunakan dan diterapkan di kehidupan nyata sehingga memudahkan otang-orang dalam menjalankan aktivitas sehari-hari. $\mathrm{Hal}$ ini tentunya mengurangi interaksi satu dengan yang lainnya di kehidupan sosial. Dunia virtual seakan menjadi wadah dalam berinteraksi yang dapat digunakan dengan mudah oleh lintas generasi. Namun, hal ini diikuti oleh menurunnya etika dan memunculkan paradoks dalam era 5.0.

Menurut Kamus Besar Bahasa Indonesia, Paradoks adalah pernyataan yang seolah-olah bertentangan dengan pendapat umum atau kebenaran, tetapi kenyataannya mengadung kebenaran. Etika masyarakat saat ini merupakan contoh nyata paradoks dalam era

http://ejournal.urindo.ac.id/index.php/TI
5.0. Etika masyarakat saat ini sangatlah berbeda dengan zaman dahulu ataupun minimal beberapa tahun lalu belakangan. Perkembangan teknologi yang ada seakan merenggut pandangan mereka dengan sekitar. Kepekaan masyarakat menjadi menurun dengan lingkungan sosial. Etika seperti sikap ramah dan bersapa menjadi hal yang cukup sulit ditemukan saat ini. Teknologi telah mengambil alih batasan di antara satu dengan yang lain sehingga etika menjadi hal terbelakang. Sebelum lebih lanjut, perlu diketahui etika adalah perbuatan yang berhubungan dengan etik. Etis adalah perbuatan yang beretika baik. Seseorang yang tidak etis adalah yang melakukan perbuatan melanggar etik (Jogiyanto HM, 2008).

Etika berbeda moral. Etika adalah sebuah ilmu sedangkan menurut kamus psikologi, moral adalah mengacu pada akhlak yang sesuai dengan peraturan sosial, atau menyangkut hukum, adat kebiasaan yang mengatur tingkah laku. Etika merupakan ilmu bukan ajaran (Franz Magniz-Suseno, 1987). Dalam perkembangan teknologi terdapat pengaruh-pengaruh untuk kehidupan sumber daya manusianya yang berhubungan dengan etika. Permasalahan yang sering muncul tentang etika dalam teknologi informasi seperti kesehatan, privacy, intelectual, property rights security, accurancy, dan lain-lain. Hal ini sebelumnya juga pernah disebutkan oleh pendiri majalah Journal of Information Ethics pada 1992, Hauptmann yang membahas kerahasiaan, keandaian, kualitas dan penggunaan informasi (Froehlich, 1997). Salah satunya yang dapat menggambarkan etika yang dinikmati setiap orang dalam perkembangan teknologi ini adalah privasi. Privasi merupakan poin penting untuk menjalani kehidupan meskipun semua sudah digital. privasi didefinisikan sebagai ruang setiap individu. Dimana hal ini yang membatasi dan mengatur kehidupan sosial yang intinya fokus pada individu dan privasi sebagai nilai sosial. Tidak dapat dipungkiri bahwa kenyataan saat ini melanggar etika teknologi informasi banyak yang berhubungan dengan privasi suatu individu yang terungkap. Dalam Privacy in Context cepat atau lambat perselihan tentang privasi diperjuangkan dengan keras dan yang terjadi penyelesaiannya memberikan keuntungan bagi pihak-pihak yang 
kuat (Nissenbaum,2009). Oleh karena itu, privasi harus dihargai bahkan dilindungi.

Kehadiran perangkat pengawasan untuk keamanan menjadi tanda era digital yang dekat. Pengawasan terus-menerus menjadi ketat dengan mengumpulkan data individu. Beberapa orang merasa ini melindungi, beberapa juga merasa malu, dan beberapa juga tidak menyukai karena hal ini mengganggu privasi mereka. Data yang dikumpulan merupakan segala bentuk informasi tentang sesorang dapat mengenai informasi pribadi maupun umum yang dapat dilihat banyak orang. Namun, hal ini tidak menjamin sebuah keamanan.

Tindakan etis atau etika seseorang sebenarnya berasal dari keyakinan pribadi. Setiap orang memiliki etikanya sendiri. Berbicara tentang perkembangan teknologi mendekati era 5.0 ini, etika dalam berteknologi informasi memang perlu diperhatikan. Menempatkan diri dengan baik di antara masyarakat dan teknologi menjadi salah satu kunci. Masyarakat sepatutnya sama-sama belajar memahami bahwa secanggih apapun teknologi saat ini, interaksi sosial itu harus tetap ada. Rasa saling membutuhkan, menolong, menghargai itu ada. Memahami situasi saat ini, memang benar jika semua serba mudah dengan hanya satu kali klik. Banyak sekali forum-forum tercipta untuk berinteraksi, belanja, dan lain-lain di dunia virtual. Dunia virtual atau dunia tidak nyata ini dihidupkan oleh masyarakat sendiri untuk berinteraksi. Tidak jarang dalam satu forum masih terdapat banyak forum lagi. Namun, tidak dipungkiri memunculkan masalah baru yang menyangkut etika informasi.

Hubungan teknologi dengan etika sangatlah erat. Hal ini tidak pada individunya saja tetapi juga organisasi dan masyarakat umum. Perkembangan teknologi informasi yang sangat pesat ini merupakan fenomena sosial yang implementasinya berimbas secara langsung. Dan masalah tentang etika ini akan terus berlanjut seiring dengan berkembangnya teknologi informasi.

\section{METODE}

Metode ini menggunakan metode penelitian kualitatif. Metode kualitatif merupakan penelitian dengan metode membandingkan hasil penelitian dan menganalisanya dengan sistematis. Metode kualitatif memiliki tujuan untuk menghubungkan data dan artefak yang ada untuk dianalisis secara objektif. Data diambil dari artikel penelitian terdahulu yang relevan.

Beberapa penelitian yang terkait dengan penelitian tentang etika teknologi informasi salah satunya ditulis oleh Dwi Prihatini (2011) tentang penggunaan teknologi informasi dengan pembajakan perangkat lunak. Penelitian ini menghasilkan faktor-faktor yang mempengaruhi penggunaan perangkat lunak bajakan di kalangan mahasiswa. Faktor yang pertama yaitu sikap yang cenderung melanjutkan suatu budaya dari generasi sebelumnya. Pembajakan perangkat lunak menjadi 'tren' di kalangan sebagian mahasiswa. Faktor kedua ekonomi keluarga disebutkan menjadi salah satu alasan mahasiswa melakukan pembajakan. Dalam hal ini gender juga mempengaruhi dimana rata-rata mahasiswa laki-laki yang melakukan hal ini. Dari penelitian ini diperlukan suatu peraturan baik dari internal maupun eksternalnya. Internal dengan menyadarkan mereka bahwa pembajakan bisa menjadi tonggak kriminal dan eksternal adalah lingkungan sekitar yang melakukan pencegahan agar meminimalisir perangkat tersebut tidak dapat dibajak. Hal yang dapat dilakukan adalah memonitoring pelaksanaan acara yang menggunakan perangkat lunak oleh pihak vendor.

Penelitian selanjutnya yang menyangkut era society 5.0 dilakukan oleh Vania Sasikirana dan Yusuf Tri Herlambang (2020) tentang tantangan urgensi pendidikan di era society 5.0. Disebutkan apakah era society 5.0 menjadi jawaban dari keresahan masyarakat dalam menghadapi era revolusi industri 4.0 sebelumnya. Kemajuan teknologi informasi yang diperkirakan memudahkan masyarakat justru menjadi menimbulkan permasalahanpermasalahan. Salah satunya di bidang pendidikan. Dalam penelitian ini diungkapkan masyarakat awam tentang teknologi terkejut dengan hal-hal yang tidak nyata atau virtual. Ditambah lagi dengan sistem pendidikan saat ini yang semua prosedur dilakukan secara online. Mulai dari PJJ (Pembelajaran Jarak Jauh), sistem 
zonasi, penilaian asesmen, dan lain-lain. Dalam ulasan yang disebutkan sebagian merasa fleksibel dengan pembelajaran yang tidak mengenal ruang dan waktu. Siswa dapat mempelajari apa saja, kapan saja dan dimana saja. Tetapi di sisi lain kebutuhan akan perangkat untuk mengikuti era ini tentu tidak murah sehingga masih banyak siswa 'gaptek' yang memerlukan literasi digital. Literasi digital tentu dibutuhkan bukan hanya untuk siswanya tetapi juga orang tua dan masyarakat. Dalam era society 5.0 ini terdapat target kemampuan yang harus dimiliki seperti literasi digital, kepemimpinan, kecerdasan emosional, kewirausahaan, kewarganegaraan global, pemecah masalah, dan kerja tim.

Dari penelitian sebelumnya yang telah dipaparkan di atas, ada beberapa pembeda dengan penelitian kami. Penelitian kami fokus pada anomali atau penyimpangan etika teknologi informasi di era 5.0. Dari penelitian sebelumnya dapat diketahui bahwa penelitian dilakukan sebelum era society 5.0 dan tidak fokus ke pembahasan etikanya.

\section{PEMBAHASAN}

Teknologi adalah sarana yang dapat memudahkan keberlangsungan kehidupan manusia dan teknologi berkembang hingga sekarang. Keberadaan teknologi tentu sangat bisa dirasakan oleh setiap orang saat ini.

\subsection{Perkembangan Teknologi}

\subsubsection{Fungsi dan Manfaat Teknologi}

Munculnya teknologi tentunya sangat banyak sekali manfaatnya bagi manusia salah satu contohnya yaitu google. Dengan adanya google kita bisa menanyakan berbagai macam hal yang tidak diketahui. Manfaat teknologi secara umum yaitu untuk memudahkan manusia dan dapat mengerjakan berbagai macam hal dengan cepat/efisien dan mudah, sehingga hasil yang diperoleh dapat lebih baik. Teknologi dapat digunakan untuk menambah wawasan dan pengetahuan secara luas serta membuat pekerjakan lebih efektif.

\subsection{2}

\section{Teknologi}

Dengan kemajuan teknologi semakin hari semakin cepat, dapat membuat banyak perubahan terhadap perkembangan sebuah negara. Dari pesatnya perkembangan teknologi informasi membawa berbagai macam pengaruh positif dan negatif. Yang dimaksud dengan dampak positif yaitu : Pertukaran informasi semakin cepat dan mudah membuat pekerjaan lebih efisien (memudahkan). Pembelajaran atau kegiatan meeting dapat dilakukan secara online tanpa harus dilakukan dengan tatap muka.

Dari sebagian contoh dampak positif yang telah disebutkan ada kemunculan dampak negatif dari kemajuan teknologi yang tidak dapat dibendung dan tidak terhindarkan. Apabila generasi muda atau yang disebut generasi millenial ini tidak dapat mengontrol diri maka dapat terjerumus ke berbagai hal negatif di antaranya : Kurangnya sosialisasi dan malas berkomunikasi antar manusia juga merupakan hal negatif karena saat ini manusia memilih segala kegiatan dengan online dan bersosislaisai dengan masyarakat sangat lamban karena terlalu fokus kepada gadget.

Banyaknya berita yang ada di masyarakat tidak selalu benar (hoax). Dan hal ini merupakan dampak negatif perkembangan teknologi karena bisa menyebabkan perpecahan, kebencian, dan permusuhan antar masyarakat. Sebagai masyarakat cerdas seharusnya kita dapat memilah mana berita yang positif dan negatif dengan benar sehingga perkembangan teknologi (komunikasi) dapat berjalan dengan baik.

\subsection{Era Society $\mathbf{5 . 0}$}

Di akhir revolusi industri 4.0, Indonesia justru mendapat kesempatan untuk berinovasi. Revolusi yang dilakukan negara Indonesia fokus pada pengembangan ekonomi digital yakni bakat dan pasar. Berkurangnya tenaga kerja karena revolusi industri 4.0, Indonesia tidak bependapat seperti itu karena revolusi indutri meningkatkan efisiensi. Inovasi baru yang terus tercipta seperti mesin, robot pintar yang mengambil peran. Tidak hanya itu saja efek kondisi industri 4.0 yang dapat kita lihat dan rasakan seperti keberadaan bisnis baru dengan inovasi dan berkolaborasi dengan teknologi. Contohnya : GO-JEK, BUKALAPAK, e-banking dan e-money.

Di era society 5.0 terdapat satu bagian yang telah masyarakat rasakan dengan jelas 
seperti revolusi Industri 4.0 dan ada pula yang belum dapat terlihat jelas seperti revolusi industri era 5.0. Revolusi industri 5.0 telah dimulai tetapi keberadaanya perlu dimatangkan. Pada revolusi industri 5.0 akan terdapat aspek yang akan mengembalikan kejayaan peradaban manusia. Salah satu hubungan bilateral negara Indonesia dan Malaysia menyatakan aspek-aspek yang berkolaborasi satu sama lain adalah digital, fisik, dan biologis serta dilengkapi dengan hadirnya aspek spiritual. "Pada Revolusi Industri 5.0 ini, agama akan kembali masuk untuk memimpin sains lagi".

Pada revolusi industri 4.0 teknologi manufaktur sudah masuk pada tren pertukaran data. Hal tersebut mencangkup sistem Internet of Things (loT), komputasi awam, cyber-fisik, dan komputasi kognitif. Dengan munculnya teknologi digital pada revolusi industri 4.0 berdampak terhadap kehidupan manusia di seluruh dunia. Perkembangan teknologi informasi yang pesat ini terjadi secara otomatis di seluruh bidang, teknologi dan pendekatan baru yang menggabungkan secara nyata, digital dan secara fundamental (Tjandrawinata, 2016).

Pada revolusi industri 4.0 ini terdapat beberapa tantangan yang dihadapi seperti kurangnya keterampilan sumber daya manusia yang memadai, masalah keamanan teknologi komunikasi, dan banyaknya yang kehilangan pekerjaan karena perubahan teknologi. Teknologi ini berdampak positif tergantung bagaimana individu dalam meminimalisir resiko dan peluang yang muncul di tranformasi revolusi industri 4.0 yang terjadi berbeda dengan apa yang dialami manusia sebelumnya.

Disisi lain, negara Jepang menyatakan dunia akan memasuki masyarakat 5.0 atau era Society 5.0 dimana masyarakat akan berpusat dengan manusia lainnya (human-centered) yang dikembangkan oleh Jepang. Society 5.0 diartikan sebagai sebuah masyarakat yang berpusat pada manusia yang menyeimbangkan kemajuan ekonomi dengan penyelesaian masalah sosial melalui sistem yang sangat mengintegrasikan ruang maya dan ruang fisik (Kabinet Jepang, 2019). Revolusi industri 4.0 yang dinilai berpotensi dalam mengurangi peran manusia membuat Jepang melahirkan sebuah konsep yaitu Society 5.0. Dengan konsep ini diharapkan membuka kecerdasan buatan akan mentranformasikan data yang besar yang dikumpulkan melalui internet pada segala bidang kehidupan menjadi sebuah budaya baru sehingga harapan untuk meningkatkan kemampuan manusia agar memberikan manfaat untuk manusia yang lain.

Perbandingan dari kedua konsep tersebut yaitu pada revolusi industri 4.0 masyarakat mencari, mengutip, dan menganalisis informasi atau data dengan mengakses layanan cloud melalui internet. Sedangkan pada Society 5.0 informasi banyak dari ruang fisik terakumulasi di cyberspace dan dianalisi oleh kecerdasan buatan, dan hasilnya diumpan kembali ke manusia dalam ruang fisik dalam berbagai bentuk.

\subsubsection{Dampak yang Ditimbulkan}

Dampak dari revolusi industri 4.0 dan 5.0 membuat kesempatan baru untuk Indonesia. Revolusi industri 4.0 justru memberi kesempatan bagi indonesia untuk berinovasi. Para ahli menilai revolusi yang fokus pada pengembangan ekonomi akan menguntungkan Indonesia.

Pengembangan ekonomi digital adalah bakat dan pasar. Indonesia berkomitmen membangun industri manufaktur yang berdaya saing global melalui percepatan industri 4.0. sebagai tandanya yaitu peluncuran Making Indonesia 4.0 sebagai sebuah strategi bahwa negara Indonesia memasuki era digital yang berjalan saat ini. Indonesia 4.0 diharapkan memberikan arah yang jelas bagi pergerakan industri nasional di masa depan. Hal ini juga termasuk fokus pada pengembangan lima sektor manufaktur yang akan menjadi percontohan. Pada penyusunan petunjuk ini melibatkan beberapa objek seperti Institusi Pemerintahan, Pelaku usaha, Asosiasi industri, Penyedia teknologi, maupun lembaga riset dan pendidikan. Melalui komitmen dan partisipasi revolusi industri 4 di Indonesia yang berjalan sukses dan sesuai sasaran yang telah ditetapkan.

Pada penerapan awal terdapat industri yang menjadi fokus implementasi revolusi industri 4.0 di Indonesia yaitu makanan dan minuman, tekstil, otomatif, elektronik, kimia dan lain-lain. Industri-industri tersebut diharapkan Indonesia membawa pengaruh besar dalam kontribusi nyata dan daya saing untuk ekonomi Indonesia menuju 10 besar ekonomi dunia tahun 
2030. Contoh implementasi industri 4.0 ialah menciptakan lapangan kerja baru dan investasi baru berbasis teknologi, menarik minat invetasi asing, meningkatkan kualitas sumber daya manusia dan lain-lain. Indonesia sudah berkomitmen untuk menerapkan Making Indonesia 4.0 sebagai agenda nasional. Dalam agenda ini terdapat peran perlahan Society 5.0 yang akan menjadi modal dasar konsep ini dapat diterima masyarakat.

Fokus menjadi Society 5.0 perlahan menjadi peluang besar bagi Indonesia untuk mempercepat transformasi di masyarakat. Indonesia optimis menerapkan sekaligus dua era yakni revolusi industri 4.0 tetap beriringan dengan Society 5.0. Peran menyadarkan masingmasing antara Pemerintah, pelaku usaha, dan masyarakat sendiri dengan mulai mengubah pola pikir dengan menghilangkan ketakutan terhadap perkembangan industri dan teknologinya. Tidak bisa dihindari bahwa perubahan besar akan terjadi. Dan semuanya akan bersama menghadapi kesulitan dan keuntungannya untuk kehidupan bermasyarakat yang berteknologi dengan baik dan bijak.

\subsection{Etika dalam Perkembangan Teknologi Informasi}

Perkembangan teknologi mempengaruhi segala aspek kehidupan manusia. Tak tekecuali aspek sosial yaitu perubahan interaksi sosial.

\subsubsection{Perbandingan Etika}

Perubahan zaman dengan segala perkembangannya menjadi tantangan juga peluang bagi setiap orang. Tantangan yang sering terjadi dalam kehidupan sosial seperti perubahan nilai sosial, peningkatan kerja secara virtual membuat terjadinya ketimpangan sosial. Sedikit berbalik ke beberapa tahun lalu saat teknologi informasi belum sepesat sekarang. Perbedaan etika amat kentara dengan saat ini. Di era saat ini meskipun disebutkan tujuannya adalah mewujudkan masyarakat yang menikmati kehidupan sepenuhnya. Namun, kenyataannya interaksi sosial semakin berkurang. Kata 'menikmati kehidupan sepenuhnya' diartikan sebagai dunia mereka sendiri.

Selain itu, sikap ramah tamah yang melekat pada jiwa manusia sosial perlahan pudar seiring perjalanan peradaban. Hal ini memang tidak dapat dipungkiri karena semakin canggihnya teknologi masyarakat lebih memilih berinteraksi lewat virtual.

\subsubsection{Permasalahan tentang Etika}

Seiring perkembangan teknologi informasi tentunya diiringi dengan permasalahan yang menyangkut etika antara lain :

\subsubsection{Privasi}

Privasi (Privacy) adalah tuntutan seseorang untuk tidak dicampuri, diawasi atau diganggu oleh orang lain atau organisasi bahkan oleh negara. (Jogiyanto, 2008). Pentingnya privasi sebagai norma yang mengatur dan menyusun kehidupan sosial. Sekalipun era digital saat ini, privasi menjadi hal yang perlu dijaga untuk menjalankan kehidupan yang memuaskan.

Berbicara pentingnya privasi bagi individu semakin intensif karena pola hidup dalam masyarakat yang semakin invidual. Oleh karena itu, kebijakan privasi membutuhkan tindakan yang cukup besar.

\subsubsection{Permasalahan Kepemilikan Intelektual}

Hak kepemilikan intelektual (Intelectual Property Rights berhubungan dengan perkembangan teknologi informasi yang memudahkan untuk ditransmisikan, disalin, ataupun diubah isinya. Kemudahan untuk melanggar hak-hak kepemilikan intelektual seseorang ini merupakan salah satu permasalahan etika.

Pembajakan perangkat lunak menjadi sesuatu yang biasa dilakukan. Beberapa mungkin belum mengetahui saat ini terdapat undangundang yang mengatur dan mengatakan bahwa ini merupakan tindakan ilegal. Alasan mengapa banyak orang memilih untuk 'dunia ke tiga' ini antara lain : menyalin perangkat lunak dapat dilakukan dimanapun, kapanpun, dan prosesnya mudah, hasil salinannya sama dengan ketika membeli, perangkat lunak yang asli harganya relatif mahal, serta beberapa beranggapan bahwa dengan menyalin peranglat lunak tidak akan menrugikan perusahaan yang memproduksinya.

\subsubsection{Permasalahan Pekerjaan}


Perkembangan teknologi informasi tentu memiliki dampak positif dan negatif misalnya untuk positif yaitu meningkatkan produktivitas, mempermudah pekerjaan, efisien terhadap waktu. Kemudian untuk negatifnya yaitu pergantian tenaga manusia dengan teknologi informasi saat ini mengurangi lapagan kerja karena dengan teknologi informasi dibutuhkan hanya sedikit pekerja.

Dalam penerapan perkembangan teknologi ini permasalahan etika dalam dunia kerja semakin banyak. Salah satunya adalah masa pensiun. Setiap karyawan tentu menginginkan masa pensiun yang layak karena telah memberikan tenaga dan fikiran untuk sebuah perusahaan dalam waktu yang lama. Namun, banyak perusahaan yang mengurangi karyawannya sedikit demi sedikit sehingga banyak karyawan yang tidak menikmati masa pensiunnya.

Pemecatan dini dalam rangka mengurangi jumlah tenaga kerja ini tentu menimbulkan permasalahan. Sebuah perusahaan sengaja membuat ' $r$ ed flag' di basis data karyawannya sehingga ketika memecatnya seolah perusahaan memiliki alasan yang cukup logis. Alasan selanjutnya yang sering digunakan adalah adanya peralatan canggih yang semakin menekan keberadaan pekerja. Perusahaan dapat dengan mudah meng-handle dengan kemajuan teknologi saat ini sehingga di sisi lain sumber daya manusia sudah mulai dikurangi dan digantikan. Padahal kenyatannya sumber daya manusia akan selalu meningkat dan lapangan kerja terus menurun. Hal ini masuk ke dalam permasalahan etika bahkan hukum. Oleh karena itu, yang harus diubah adalah sumber daya manusianya. Ditingkatkan kemampuannya dengan memanfaatkan teknologi yang sedang berkembang pesat saat ini sehingga dapat membuka lapangan pekerjaan untuk yang lainnya.

\subsubsection{Permasalahan Keamanan}

Permasalahan ini menimbulkan masalah etika dalam perubahan era dan perkembangan teknologi saat ini. Seringkali terjadi penanganan keamanan dinilai kurang karena kelalaian atau kesengajaan suatu pihak. Salah satunya yang sering terjadi adalah masalah kata sandi yang kerap terjadi 'pembobolan' di setiap bidang yang menggunakan kemajuan iptek ini. Oleh karena itu, perlu adanya smart security yang baik, layak, dan sulit terpecahkan untuk masalah kata sandi.

\section{HASIL}

\subsection{Fakta di Masyarakat}

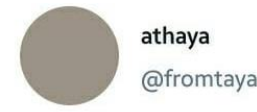

Hari ini dapat telepon dari yang mengaku cs alodokter, dia tahu nomor dan email w, katanya mau ngasih hadiah santunan 2jt. W bahkan nggak punya aplikasinya lagi di hp... kok bisa bisanya dapat hadiah(?) Setelah w cari di google korbannya udah banyak

Terjemahkan Tweet

๑ $九 \quad 0 \quad \infty_{0}^{\circ}$

Gambar 1. Contoh pelanggaran Privasi

Dari Gambar 1 dapat diketahui bahwa dunia maya menjadi salah satu tempat yang menyimpan identitas penggunanya. Tidak dpungkiri bahwa hal ini dimanfaatkan oleh oknum-oknum tidak bertanggung jawab yang memiliki tujuan untuk keuntungan pribadi. Hal ini termasuk paradoks etika masyarakat dalam memanfaatkan teknologi yang ada. 


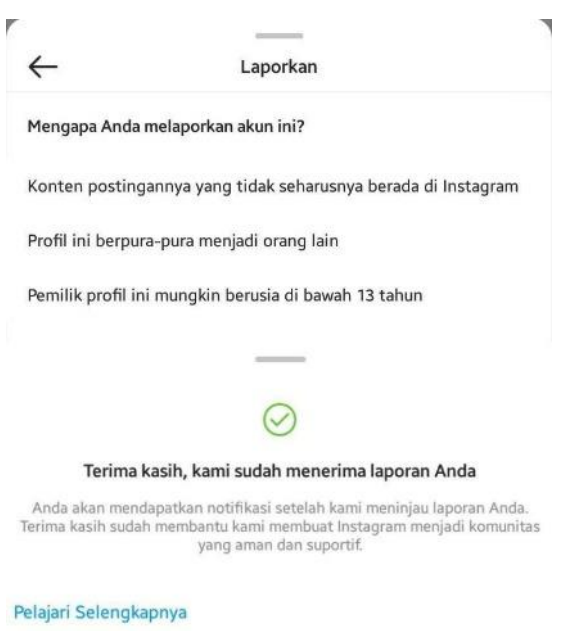

Gambar 2. Fitur keamanan yang ada

Dari Gambar 2 dapat dilihat bahwa terdapat fitur-fitur yang melindungi privasi pengguna. Pengguna dapat melaporkan ketika ada pengguna lain mencoba menggunakan akun miliknya. Tidak hanya itu fitur pada forum virtual seperti ini sangat penting untuk ada sehingga pengguna merasa aman dan nyaman dalam berinteraksi secara virtual.

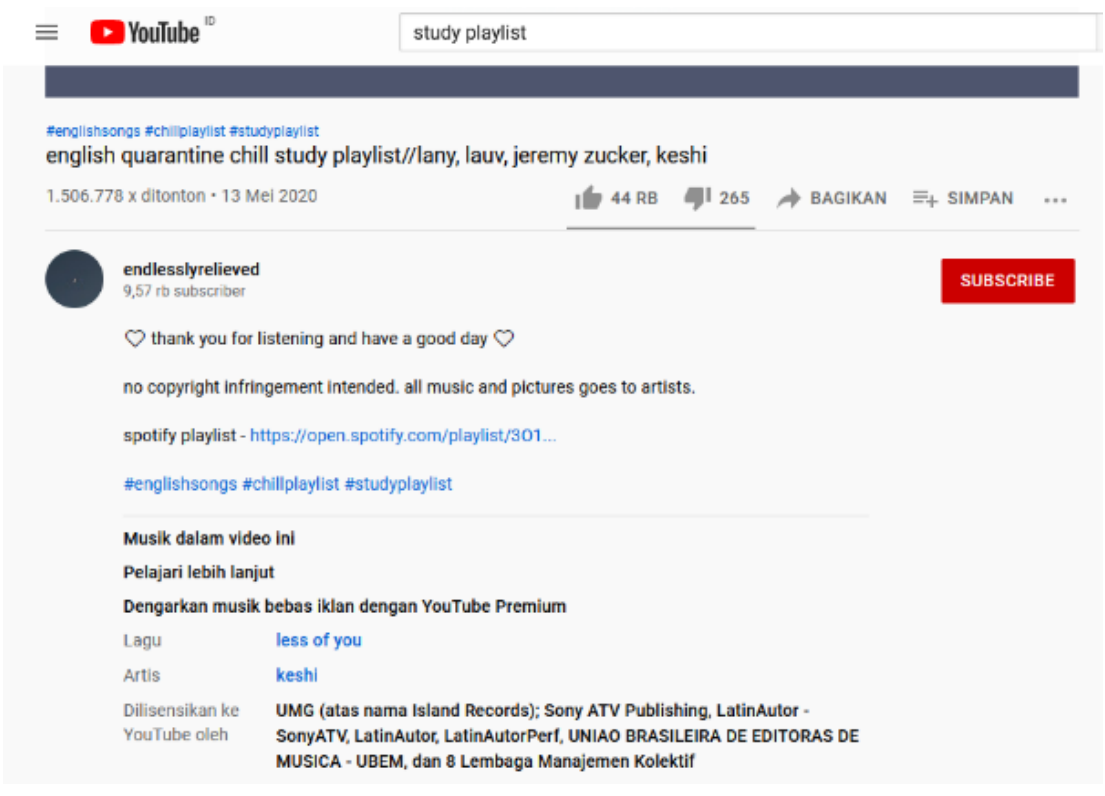

\section{Gambar 3. Sistem Copyright}

Kepemilikan Intelektual menjadi hak pemilik atau pencipta. Seseorang, orang lain, atau pihak lain tidak boleh menyalin apa yang telah menjadi ciptaan pemilik. Sistem seperti ini sangat diperlukan untuk melindungi hak cipta juga menghargai sang maestro. Di era saat ini, orang lain dengan mudah mengambil, meng-copy, menyalin karya orang lain sehingga hal ini harus diperhatikan. Dengan sitem ini diharapkan 
semua elemen masyarakat dapat menghasilkan dan menunjukkan kreativitas masing-masing.

\section{KESIMPULAN}

Berdasarkan hasil dan pembahasan etika masyarakat di era Society 5.0 memerlukan edukasi yang cukup. Hal ini agar masyarakat tetap menjaga etika meskipun di dunia virtual. Bukan hanya masyarakat saja melainkan seluruh lapisan masyarakat perlu adanya etika

\section{DAFTAR PUSTAKA}

1. Aslam, F., Aimin, W., Li, M., \& Rehman, K. U. (2020). Innovation in the era of loT and industry 5.0: Absolute innovation management (AIM) framework. Information (Switzerland), 11(2). https://doi.org/10.3390/info11020124

2. Becker, M. (2019). Privacy in the digital age: comparing and contrasting individual versus social approaches towards privacy. Ethics and Information Technology, 21(4), 307-317. https://doi.org/10.1007/s10676-01909508-z

3. Csoklich, P. (2018). Article 2. Commercial Law, August, 906-909. https://doi.org/10.5771/978384527656 4-906

4. Csoklich, P., Zhu, L., Csr, P. S., Sosial, K., Csr, P. S., Sosial, K., Nurwati, R. N., \& Becker, M. (2020). TRANSFORMASI PRAKTIK PEKERJAAN SOSIAL MENUJU MASYARAKAT 5 . O TRANSFORMATION OF SOCIAL WORK PRACTICES TOWARD SOCIETY 5 . 0 Meilanny Budiarti Santoso Maulana Irfan PENDAHULUAN Perubahan adalah sebuah keniscayaan, sekaligus menjadi tantangan dan peluang ba. Commercial Law, 6(4), 307317.https://doi.org/10.5771/97838452 76564-906

5. 5. Csr, P. S., Sosial, K., Csr, P. S., Sosial, K., \& Nurwati, R. N. (2020). TRANSFORMASI PRAKTIK PEKERJAAN SOSIAL MENUJU MASYARAKAT 5 . O TRANSFORMATION OF SOCIAL WORK PRACTICES TOWARD SOCIETY 5.0.

6. Danuri, M. (2019). Development and berteknologi informasi yang baik sehingga terjadi kesimbangan antara dunia nyata dan dunia virtual. Kemajuan teknologi dan perubahan era digital seharusnya disikapi dengan baik. Sisa era revolusi industri 4.0 masih dijalankan oleh masyarakat sehingga memerlukan adanya kesiapan dalam menyambut era society 5.0 .

Transformation of Digital Technology. Infokam, XV(II), 116-123.

7. Danuri, M., Komputer, I., Nuswantoro, U. D., Internet, P., \& Informasi, T. (2017). TREND CYBER CRIME DAN TEKNOLOGI INFORMASI DI. 55-65.

8. Engineering, E. (2019). 21-Article Text71-1-10-20190510 society 5.0. 02(01), $67-79$.

9. Gunawan, H. (2012). Jurnal Integrasi ISSN : 2085-3858 ( print version ) Article History Received 13 February 2012 Accepted 16 March 2012 Gender dalam Perspektif Academic Self-Efficacy dan Kecurangan Teknologi Informasi. 4(1), 107-110.

10. Informasi, E. (1980). Etika Informasi. 26(1), 4-11.

11. Laudon, K. C. (1995). Ethical Concepts. 38(12), 33-39.

12. Paduppai, A. M., Hardyanto, W., Hermanto, A., \& Yusuf, A. (2019). Pengembangan Sistem Informasi Manajemen dalam Peningkatan Mutu Layanan Pendidikan dan Android di Era Revolusi Digital (Society 5.0 dan Revolusi Industri 4.0). Prosiding Seminar Nasional Pascasarjana UNNES, 84-89. https://proceeding.unnes.ac.id/index.p hp/snpasca/article/download/250/211 
13. Rahmawati, D. (2012). Analisis Faktor Faktor yang Berpengaruh Terhadap Pemanfaatan Teknologi Informasi. Jurnal Ekonomi Dan Pendidikan, 5(1), 107-118.

https://doi.org/10.21831/jep.v5i1.606

14. Sabri, I. (2019). Peran Pendidikan Seni Di Era Society 5 . 0 untuk Revolusi Industri 4.0. Seminar Nasional Pascasarjana 2019, 2(1), 342-347. https://proceeding.unnes.ac.id/index.p $\mathrm{hp} /$ snpasca/article/view/302
15. Zhu, L. (2011). Privacy in Context: Technology, Policy, and the Integrity of Social Life. Journal of Information Privacy and Security, 7(3), 67-71. https://doi.org/10.1080/15536548.201 1.10855919 